\title{
BMJ Open What's on your keyboard? A systematic review of the contamination of peripheral computer devices in healthcare settings
}

\author{
Nicole Ide, ${ }^{1}$ Bianca K Frogner, ${ }^{1}$ Cynthia M LeRouge, ${ }^{2}$ Patrick Vigil, ${ }^{3}$ \\ Matthew Thompson ${ }^{1}$
}

To cite: Ide N, Frogner BK, LeRouge CM, et al. What's on your keyboard? A systematic review of the contamination of peripheral computer devices in healthcare settings. BMJ Open 2019;9:e026437. doi:10.1136/ bmjopen-2018-026437

- Prepublication history and additional material for this paper are available online. To view these files, please visit the journal online (http://dx.doi. org/10.1136/bmjopen-2018026437).

Received 4 September 2018 Revised 15 January 2019 Accepted 30 January 2019

Check for updates

(c) Author(s) (or their employer(s)) 2019. Re-use permitted under CC BY-NC. No commercial re-use. See rights and permissions. Published by BMJ.

${ }^{1}$ Department of Family Medicine, University of Washington,

Seattle, Washington, USA

${ }^{2}$ Department of Information Systems \& Business Analytics,

Florida International University,

Miami, Florida, USA

${ }^{3}$ Family Medicine, Pacific Northwest University, Yakima, Washington, USA

Correspondence to Dr Matthew Thompson; mjt@uw.edu

\section{ABSTRACT}

Objective To determine the extent and type of microbial contamination of computer peripheral devices used in healthcare settings, evaluate the effectiveness of interventions to reduce contamination of these devices and establish the risk of patient and healthcare worker infection from contaminated devices.

Design Systematic review

Methods We searched four online databases: MEDLINE, CINAHL, Embase and Scopus for articles reporting primary data collection on contamination of computer-related equipment (including keyboards, mice, laptops and tablets) and/or studies demonstrating the effectiveness of a disinfection technique. Pooling of contamination rates was conducted where possible, and narrative synthesis was used to describe the rates of device contamination, types of bacterial and viral contamination, effectiveness of interventions and any associations between device contamination and human infections.

Results Of the 4432 records identified, a total of 75 studies involving 2804 computer devices were included. Of these, 50 studies reported contamination of computerrelated hardware, and 25 also measured the effects of a decontamination intervention. The overall proportion of contamination ranged from $24 \%$ to $100 \%$. The most common microbial contaminants were skin commensals, but also included potential pathogens including methicillinresistantStaphylococcus aureus, Clostridiumdifficile, vancomycin-resistantenterococci and Escherichia coli. Interventions demonstrating effective decontamination included wipes/pads using isopropyl alcohol, quaternary ammonium, chlorhexidine or dipotassium peroxodisulfate, ultraviolet light emitting devices, enhanced cleaning protocols and chlorine/bleach products. However, results were inconsistent, and there was insufficient data to demonstrate comparative effectiveness. We found little evidence on the link between device contamination and patient/healthcare worker colonisation or infection. Conclusions Computer keyboards and peripheral devices are frequently contaminated; however, our findings do not allow us to draw firm conclusions about their relative impact on the transmission of pathogens or nosocomial infection. Additional studies measuring the incidence of healthcare-acquired infections from computer hardware, the relative risk they pose to healthcare and evidence for effective and practical cleaning methods are needed.
Strengths and limitations of this study

- This is the first systematic review on the level of contamination of computer peripheral devices used in clinical care as well as the effectiveness of interventions used to decontaminate these surfaces.

- We searched four major online databases during the literature search and hand searched references of included studies and relevant review articles.

- Reporting of this review adhered to the Preferred Reporting Items for Systematic Reviews and MetaAnalyses guidelines.

- The ability to perform meta-analysis was limited by the heterogeneity among the included studies.

\section{INTRODUCTION}

The annual number of healthcare-acquired infections (HAIs) in the US acute care hospitals is estimated at approximately 722000 , or $4 \%$ of inpatients. ${ }^{1}$ HAIs lead to longer admissions, more frequent readmissions and poorer patient outcomes including increased mortality. ${ }^{2}{ }^{3}$ The US Centers for Disease Control and Prevention (CDC) estimates that preventing HAIs in the USA would result in annual direct savings of between US $\$ 5.7$ and US\$31.5 billion. ${ }^{4}$ Studies to date have largely focused on hospital settings; thus, the frequency of consequences of HAIs in outpatient settings is poorly described.

Between $20 \%$ and $40 \%$ of HAIs result from cross-infection via hands of personnel, and another $20 \%$ from other environmental contamination. ${ }^{5}$ Contamination of environmental surfaces in healthcare settings is a well-known source of nosocomial infection, and several pathogens have been identified on surfaces in hospital environments, including methicillin-resistant Staphylococcus aureus (MRSA), Clostridium difficile (C. diff), Acinetobacter baumannii, vancomycin-resistant enterococci (VRE), Pseudomonas aeruginosa, 
Norovirus and Gram-negative bacteria. ${ }^{6-9}$ Nosocomial pathogens often originate from infected patients who come into contact with the surfaces surrounding them, particularly 'high-touch surfaces', and are then transferred to other healthcare workers' or patients' hands.

Several studies looking at healthcare workers' personal devices (mobile phones or personal digital assistants (PDAs)), clothing (neckties, white coats, etc) and a variety of other objects (stethoscopes, blood pressure cuffs, telephones, faucets, bedrails, etc) have found significant rates of environmental contamination. ${ }^{6} 1011$ However, the importance of contamination related specifically to computer keyboards, mice and other computer peripherals is less well established despite their ubiquitous use in hospital and ambulatory healthcare settings.

We, therefore, conducted a systematic review to determine the extent to which computer keyboards, mice and other computer peripheral devices have been identified as being a source of contamination in clinical settings. We examine the type and prevalence of microbial contamination, and the settings in which these contaminated devices have been addressed. We also determined the effectiveness of interventions that aim to reduce contamination of these devices, and any evidence linking clinical consequences of HAI related to computer keyboards/ peripherals among patients and healthcare workers.

\section{METHODS}

We report this systematic review in accordance with the Preferred Reporting Items for Systematic Reviews and Meta-Analyses (PRISMA) guidelines, an evidence-based minimum set of items recommended for reporting of systematic reviews. ${ }^{12}$ A PRISMA checklist can be found in online supplementary file 1.

\section{Search strategy}

A total of four databases were included in our search: MEDLINE, CINAHL, Embase, and Scopus. We developed two major categories of search terms that were used in various combinations to search the databases. First, terminology related to peripheral and external computer hardware devices, such as mice and keyboards. Second, terminology related to infection, contamination or disinfection (online supplementary file 2). We conducted automated searches in databases from 01 January 1990 to 14 July 2017. We limited the search to this time frame due to the low rates of computer use in clinical settings prior to 1990 . Additionally, we manually searched the references of included studies and relevant review articles to identify further eligible studies, and where possible, we contacted authors to obtain full texts of abstracts if not available online.

\section{Eligibility criteria and study selection}

We included studies that met the following criteria: (A) conducted in any type of healthcare setting in a high-income or upper-middle-income country, ${ }^{13}$ investigated keyboards, mice, mouse pads, computer touch screens, laptops and iPads/tablet computers, (C) reported primary data collected through experimental, quasi-experimental or observational study designs, (D) reported contamination rates of computer-related equipment and/or demonstrated the effectiveness of disinfection technique(s), (E) reported any association between contamination of computer-related equipment and infection or colonisation of patients/healthcare workers and (F) written in English language.

We excluded studies that were not conducted in a healthcare setting or were conducted in low-income or lower-middle-income countries (where pathogenic microbes are potentially different to those found in high-income or upper-middle-income countries), tested computer-related equipment with in vitro experiments, reported solely data on environmental surfaces other than computer-related hardware, or assessed healthcare worker knowledge or compliance with disinfection or hand-washing protocols. We excluded all studies that only provided an abstract.

After searching the four databases, we uploaded articles to EndNote X8 and removed any duplicates. One reviewer (NI) screened titles and abstracts to remove clearly irrelevant studies. Two reviewers (NI and MT) independently screened the full text of all remaining articles to determine final eligibility, and resolved any discrepancies through discussion and consensus.

\section{Data extraction and quality assessment}

Using a standardised form in Microsoft Excel, asingle reviewer (NI) extracted the following data from each included article: country and clinical setting, study design, sampling frame and size, microbiological sampling method, microbiological identification method, outcome measure(s), intervention definition (if any), comparison (if any), ongoing decontamination methods (if any) and results (baseline contamination rates, baseline pathogens detected and post-intervention contamination rate). Extracted data were checked for accuracy by a second author (MT), and disagreements were resolved prior to analysis.

Two authors (NI and MT) independently assessed the methodological quality and risk of bias using checklists we developed based on The National Heart, Lung, and Blood Institute's study quality assessment tool ${ }^{14}$ as well as criteria developed in a relevant systematic review by Livshiz-Riven et al, which assessed the relationship between contamination and non-invasive portable clinical environmental surfaces. ${ }^{15}$ To assess the risk of bias for each outcome, we developed two separate checklists: one for studies reporting only baseline contamination and another for studies that included an intervention. We looked at the quality of individual studies and assessed the risk of bias on the basis of study design, objectives, sampling strategy, microbial detection methods, outcome measurement and reporting, and confounding variables. For studies of decontamination interventions, we also assessed intervention characteristics and comparisons or controls. Each assessment item was 
scored as 'Yes', 'No' or 'Unclear'. The overall risk of bias of the body of evidence was considered in the interpretation of findings of the review.

\section{Summary measures}

For studies reporting contamination of peripheral computer-related hardware devices, we present findings as the proportion of devices contaminated, using definitions of contamination as reported in individual studies. For studies reporting the effectiveness of a decontamination intervention, we present findings as a change (or percentage change) in contamination rates following the intervention, as reported by the respective authors. We explored whether there were differences in contamination rate between clinical settings, countries or types of devices. We intended to use meta-analysis to pool results, but due to heterogeneity in study design, interventions and outcomes reported, this was not possible. A simple pooled mean of baseline contamination of the studies, which included an overall baseline rate of device contamination, was calculated.

\section{Patient and public involvement}

Neither patients nor the public was involved in the development of the research question or study design for this systematic review. Results will be made available to the public by publishing this study in a peer-reviewed, open access journal.

\section{RESULTS}

\section{Study selection}

Our search identified 4416 records, with an additional 24 identified through a manual search. After removing duplicates, we screened the remaining 3920 articles based on our inclusion criteria. Of these, 174 were selected for full-text review, of which 99 did not meet our criteria and were excluded, leaving a total of 75 studies in the final analysis (figure 1). ${ }^{16-90}$

\section{Study characteristics}

Of the 75 included studies (online supplementary file 3 ), only one was published prior to the year 2000, with another 27 studies published between 2000 and 2009, and 47 studies published 2010 onwards. Most were conducted either in the USA or Canada (26) or Europe/Central Asia (28), followed by Southeast/East Asia or the Pacific (12), Middle East (4), South America (4) and South Africa (1).

The vast majority (63) of studies were conducted only in hospitals, including intensive care units (ICUs) (12 conducted solely in ICU and an additional 17 studies

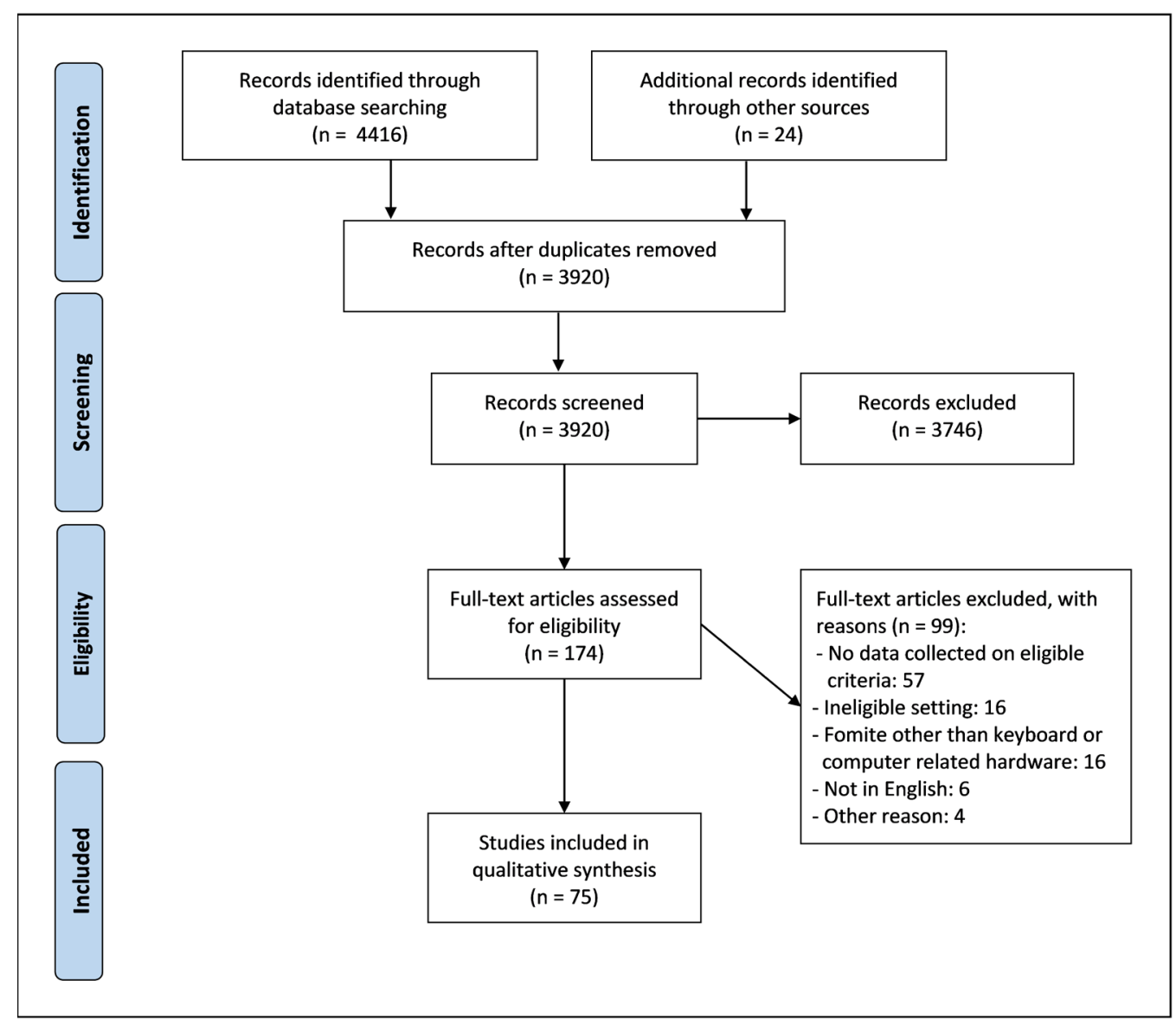

Figure 1 Flow diagram of study selection. 
included ICU as one of their settings), emergency department (11) and operating rooms (8). Twelve studies were conducted in a variety of other clinical settings, including dental clinics or a dental hospital, radiology settings, an outpatient ophthalmology clinic, a pharmacy practice or a mixed setting.

Overall, the included studies provided data on a total of 2804 devices, including 1482 keyboards, 665 computer stations and 398 mice or mouse pads. Nineteen studies did not explicitly state the number of devices tested or only reported the total number of samples taken. Keyboards were the most commonly studied peripheral computer device, with 42 studies testing keyboards alone and another 22 testing a combination of keyboards plus mice. Fewer tested tablets (5) or mice alone (2). The numbers of devices sampled ranged from a single keyboard up to 282 computer stations (keyboards plus mice).

The majority of studies (50) reported primarily on device contamination rates (mostly using cross-sectional samples). ${ }^{17-23} 262932-363841-46495052-566062$ 64-66 68-76 81-86 90 Another 25 studies used interventional

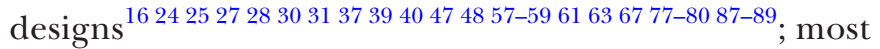
reported contamination rates before and after a disinfection or cleaning process (and therefore also contributed data on baseline contamination rates). One study only reported contamination postintervention, ${ }^{61}$ and another two reported only on an association between device contamination and patient colonisation rates. ${ }^{638}$ Of the 25 studies reporting interventions, most used pre-post designs (17), with a smaller number (8) using controlled trials, postintervention study, cross-over or prospective comparative analysis. A variety of methods were used to measure effectiveness, including change in rate of overall contamination (11), change in rate of specific pathogens (5), change in colony forming unit (CFU) values (3), reduction in both rates and CFU values (2), rate of keyboards with contamination over $500 \mathrm{CFU}$ (1), number of acquired colonisations preintervention and postintervention (1), patient acquisition of MRSA (1) and contamination rate for postintervention phase only (1).

\section{Prevalence of baseline contamination}

A total of 71 studies provided data on levels of device contamination. Of these, 26 presented an overall proportion of microbial contamination (table 1), with contamination rates ranging from $24 \%$ to $100 \%$. Of these 26 studies, 21 reported the proportion of devices contaminated, while five reported the proportion of collected swabs that were contaminated. Of the 21 studies reporting device contamination, the pooled mean contamination rate was $96.7 \%$ (range $80 \%$ to $100 \%$ ).

A further 12 studies reported overall contamination only as CFU (online supplementary file 4), and another 10 reported contamination using a variety of other methods, such as proportion of devices with multiple bacterial species identified, mean bacterial counts, aerobic colony counts or ATP values/failures (online supplementary file
5). A further 23 studies reported baseline contamination of only a single or few specific pathogens: 20 as a proportion $(\%)$ of each pathogen, one presented total bacterial counts $($ mean $\pm \mathrm{SD})$ and two reported the existence of specific pathogens without quantifying them (online supplementary file 6 ).

The range of overall contamination was wide: while most studies found a contamination rate of $80 \%-100 \%$, Bures et al reported a rate of $24 \%$ in a study of keyboards in ICU patient rooms and nurse/doctor stations, ${ }^{20}$ while Smith et al reported a rate of $43 \%$ on notebook computers from medical, surgical and family practice programmes. ${ }^{78}$ However, we were unable to determine differences in contamination rates between clinical settings, countries or types of devices due to insufficient data.

\section{Type of microbial contamination}

The specific pathogens isolated from keyboards or other computer devices was reported in 63 studies. Of these, 49 reported the proportion of devices contaminated with specific types of bacteria (online supplementary file 7). The most frequent microbial contaminants were skin commensal bacteria, but contamination with a variety of potentially pathogenic bacteria was also reported. The most frequent potential pathogens identified included Staphylococcus aureus ( $S$. aureus) and MRSA, but this depends on whether studies set out to detect all microbe or pathogens, or only specific organisms. Of the studies reporting contamination with $S$. aureus, the mean contamination rate was $28 \%$ (range $1 \%-94 \%$ ). Mean rates of contamination with MRSA was $14 \%$ (range $0 \%-100 \%$ ), VRE 3.7\% (range $0 \%-12 \%$ ) and C. diff $8.0 \%$ (range $0 \%-28 \%)$.

\section{Effectiveness of decontamination interventions}

Twenty-five studies evaluated the effectiveness of disinfection or cleaning interventions on the level of device contamination. Of these, 14 reported statistically significant reductions in contamination following the intervention (table 2). These included seven studies using wipes/pads with isopropyl alcohol, quaternary ammonium, chlorhexidine or dipotassium peroxo-

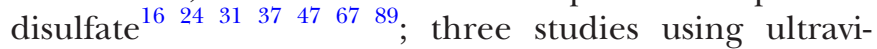
olet (UV) light 3957 ; ; two studies using putty cleaning compound $^{5859}$; one study with an enhanced cleaning protocol (including glove use ${ }^{63}$ and one study using a keyboard with a cleaning alarm. ${ }^{87}$

A further eight studies reported reductions in contamination from interventions (online supplementary file 8 ), but reductions were not statistically significant, ${ }^{78}$ not tested using statistical tests, ${ }^{28} 487980$ or did not apply the statistical tests specific to data from the computer devices. ${ }^{27} 3040$ Effectiveness of interventions in an additional two studies was unclear due to poor reporting of baseline and/or postintervention contamination rates (online supplementary file 8 ). ${ }^{2561}$ 
Table 1 Studies reporting the proportion of computer devices contaminated

\begin{tabular}{|c|c|c|c|}
\hline Author, year & Clinical setting & Device and number & Proportion contaminated \\
\hline Bures et $a l^{20} 2000$ & $\begin{array}{l}\text { ICU (patient rooms and } \\
\text { nurse+doctor stations) } \\
\text { USA }\end{array}$ & $\begin{array}{l}10 \text { keyboards } \\
\text { (80 total swabs) }\end{array}$ & $19 / 80(24 \%)$ \\
\hline Codish et $a^{24} 2015$ & $\begin{array}{l}\text { Internal medicine wards and ICU } \\
\text { Israel }\end{array}$ & 81 keyboards +81 mice & $\begin{array}{l}\text { Internal medicine: } 92 / 92(100 \%) \\
\text { ICU: } 62 / 70(88.6 \%) \\
\text { Total: } 154 / 162(95.1 \%)\end{array}$ \\
\hline Cordeiro et al ${ }^{25} 2015$ & $\begin{array}{l}\text { ICU in a medium-sized hospital } \\
\text { Brazil }\end{array}$ & $\begin{array}{l}\text { Six keyboards } \\
\text { (12 total swabs) }\end{array}$ & $6 / 6(100 \%)$ \\
\hline De Grood et $a l^{28} 2012$ & $\begin{array}{l}\text { Medical, surgical and ICU units in } \\
\text { four urban hospitals } \\
\text { Canada }\end{array}$ & $\begin{array}{l}\text { Two studies: } \\
\text { 1) } 230 \text { keyboards } \\
\text { 2) } 10 \text { Cleankeys keyboards }\end{array}$ & $\begin{array}{l}\text { 1) } 229 / 230(99.6 \%) \text { contaminated with } \\
\text { CNS, Micrococcus spp., diphtheroids, } \\
\text { Bacillus spp. or alpha streptococci. } \\
154 / 230(67 \%) \text { found positive with solid } \\
\text { agar and broth for any one of the } 3 \text { cultures } \\
\text { taken (MSSA, MRSA, Enterococcus [non- } \\
\text { VRE and VRE], GNB, C. diff, yeast and } \\
\text { fungus). } \\
\text { 2) } 10 / 10(100 \%)\end{array}$ \\
\hline Duszak et al ${ }^{31} 2014$ & $\begin{array}{l}\text { Outpatient radiologist workstations in } \\
\text { two hospitals in two US states }\end{array}$ & Seven mice & $7 / 7(100 \%)$ \\
\hline Gostine et a/ 2016 & $\begin{array}{l}\text { ICU } \\
\text { USA }\end{array}$ & $\begin{array}{l}40 \text { keyboards } \\
\text { (203 total swabs) }\end{array}$ & 193/203 (95.1\%) \\
\hline Gray et al 2007 & $\begin{array}{l}\text { ED at a tertiary referral hospital } \\
\text { Northern Ireland }\end{array}$ & $\begin{array}{l}\text { Seven mice } \\
\text { (63 total swabs) }\end{array}$ & $54 / 63(85.7 \%)$ \\
\hline Hassan ${ }^{44} 2014$ & $\begin{array}{l}\text { Staff rooms, computer labs and } \\
\text { internet centres in a teaching hospital } \\
\text { Iraq }\end{array}$ & 150 keyboards and 100 mice & $242 / 250(99.2 \%)$ \\
\hline Hong et al ${ }^{46} 2012$ & $\begin{array}{l}\text { ED of three teaching hospitals } \\
\text { South Korea }\end{array}$ & 56 keyboards and 56 electronic & $103 / 112(92.0 \%)$ \\
\hline $\begin{array}{l}\text { Karbasizade et al }{ }^{49} \\
2014\end{array}$ & $\begin{array}{l}\text { Medical wards of various hospitals } \\
\text { Iran }\end{array}$ & 65 keyboards & $64 / 65(98.5 \%)$ \\
\hline $\begin{array}{l}\text { Keerasunt- } \\
\text { onpong et al } 2017\end{array}$ & $\begin{array}{l}\text { Patient care areas in general medical } \\
\text { wards and ICU in a hospital } \\
\text { Thailand }\end{array}$ & 26 keyboards & $25 / 26(96.2 \%)$ \\
\hline Khan et $a l^{51} 2015$ & $\begin{array}{l}\text { Two large academic institutions and } \\
\text { medical centres } \\
\text { USA }\end{array}$ & $\begin{array}{l}106 \text { portable electronic devices } \\
\text { (93 iPads/tablet) }\end{array}$ & $\begin{array}{l}100 \% \text { had at least one positive culture from } \\
\text { screen or cover. }\end{array}$ \\
\hline Martin et $a l^{57} 2011$ & $\begin{array}{l}\text { ICU and ED in a paediatric hospital } \\
\text { USA }\end{array}$ & $\begin{array}{l}24 \text { terminals (keyboards/mouse/ } \\
\text { pad) }\end{array}$ & $23 / 24(96 \%)$ \\
\hline Messina et a $/^{59} 2013(\mathrm{~B})$ & $\begin{array}{l}\text { Various units within three hospitals } \\
\text { Italy }\end{array}$ & 50 keyboards & $\begin{array}{l}\text { With PCA } 36^{\circ} \mathrm{C}-49 / 50(98 \%) \\
\text { With PCA } 22^{\circ} \mathrm{C}-33 / 50(66 \%)\end{array}$ \\
\hline Patel et al ${ }^{67} 2010$ & $\begin{array}{l}\text { Four different areas of a dental } \\
\text { hospital (two student study areas and } \\
\text { two clinics) } \\
\text { UK }\end{array}$ & Eight keyboards & $\begin{array}{l}100 \% \text { contaminated with a variety of } \\
\text { microorganisms including S. aureus, CNS, } \\
\text { GNR and cocci. }\end{array}$ \\
\hline $\begin{array}{l}\text { Richard and Bowen }{ }^{72} \\
2017\end{array}$ & $\begin{array}{l}\text { Orthopaedic OR } \\
\text { USA }\end{array}$ & Six keyboards & $100 \%$ \\
\hline Rutala et $a l^{73} 2006$ & $\begin{array}{l}\text { Burn ICU, cardiothoracic ICU and } \\
\text { nursing units } \\
\text { USA }\end{array}$ & 25 keyboards & $\begin{array}{l}25 \text { keyboards }(100 \%) \text { had growth of two or } \\
\text { more microorganisms. }\end{array}$ \\
\hline Schultz et al 2003 & $\begin{array}{l}\text { Veterans Affairs hospital: areas close } \\
\text { to patients in high use areas of the } \\
\text { acute, ambulatory and long-term care } \\
\text { areas } \\
\text { USA }\end{array}$ & 100 keyboards & $95 / 100(95 \%)$ \\
\hline Shaikh et al $^{77} 2016$ & $\begin{array}{l}\text { Lab and medical wards } \\
\text { USA }\end{array}$ & 25 keyboards & $\begin{array}{l}20 / 25 \text { ( } 80 \%) \text { including GNB, C. diff, } \\
\text { Enterococcus spp. or S. aureus. }\end{array}$ \\
\hline Smith et al ${ }^{78} 2006$ & $\begin{array}{l}\text { Medical, surgical and family practice } \\
\text { programmes } \\
\text { USA }\end{array}$ & $\begin{array}{l}60 \text { notebook keys and grips } \\
\text { (120 total swabs) }\end{array}$ & $\begin{array}{l}52 / 120 \text { cultures ( } 43 \%) \text { contaminated } \\
\text { Significant pathogens found in only } 1.7 \% \text { of } \\
\text { cultures (MSSA and Serratia species). }\end{array}$ \\
\hline
\end{tabular}


Table 1 Continued

\begin{tabular}{|c|c|c|c|}
\hline Author, year & Clinical setting & Device and number & Proportion contaminated \\
\hline $\begin{array}{l}\text { Sweeney and Dancer } \\
2009\end{array}$ & $\begin{array}{l}\text { Various clinical wards and ED } \\
\text { UK }\end{array}$ & $\begin{array}{l}68 \text { computer terminals } \\
\text { (keyboards/mice) }\end{array}$ & $67 / 68$ (98.5\%) \\
\hline Tan et a/82 2013 & $\begin{array}{l}\text { Two open wards in } 800 \text { bed acute } \\
\text { care hospital } \\
\text { Singapore }\end{array}$ & $\begin{array}{l}\text { Unknown number of keyboards } \\
\text { Six total samples }\end{array}$ & $6 / 6(100 \%)$ \\
\hline Waghorn et $a l^{84} 2005$ & $\begin{array}{l}\text { General medical, general surgical, } \\
\text { orthopaedic, care of the elderly, } \\
\text { dermatology and paediatric wards, } \\
\text { ICU, ED, OPD, and theatre suite } \\
\text { UK }\end{array}$ & 48 keyboards & $\begin{array}{l}100 \% \text { grew organisms of some kind. } \\
79 \% \text { of sampled computers grew either } \\
\text { moderate or heavy numbers of organisms. }\end{array}$ \\
\hline Westerway et al ${ }^{85} 2017$ & $\begin{array}{l}\text { Ultrasound units in public hospital } \\
\text { and private practice } \\
\text { Australia }\end{array}$ & 10 ultrasound keyboards & $\begin{array}{l}100 \% \text { of samples had } 10 \text { or more colonies } \\
\text { (highest level of contamination). }\end{array}$ \\
\hline Wilson et $a l^{86} 2006$ & $\begin{array}{l}\text { ICU-bedside and nurse station } \\
\text { UK }\end{array}$ & 17 keyboards & $\begin{array}{l}100 \% \text { contaminated with at least one } \\
\text { species. }\end{array}$ \\
\hline
\end{tabular}

C. diff, Clostridium difficile; CNS, coagulase-negative staphylococcus; ED, emergency department; GNB, Gram-negative bacilli; GNR, Gramnegative rods; ICU, intensive care unit; MRSA, methicillin-resistant Staphylococcus aureus; MSSA, methicillin-susceptible Staphylococcus aureus; OPD, outpatient department; OR, operating room; PCA, plate count agar; S. aureus, Staphylococcus aureus; VRE, vancomycinresistant Enterococcus.

\section{Association between device contamination and clinical infection}

Only five included studies examined the association between device contamination and infection or colonisation of patients/healthcare workers (online supplementary file 9). Of these, three reported an association showing that the decontamination intervention was associated with reductions in the rate of MRSA infections, ${ }^{27}$ $\mathrm{VRE}^{40}$ and Acinetobacter colonisations. ${ }^{63}$ However, the link between association and causation in these studies was unclear and open to bias. One study showed that even though $12.5 \%$ of positive blood cultures matched the organisms growing from surveillance sites, this correlation was not significant, ${ }^{70}$ and one showed no effect of a cleaning intervention on patient acquisition of MRSA. ${ }^{88}$

\section{Quality assessment}

For studies that reported contamination rates, sampling methods were often convenience-based, and only six used a power calculation to guide sample size. In 19 studies, the number of included devices was not explicitly stated, and denominators were reported inconsistently. In 44 out of 75 studies, selection criteria for the devices were not given and not clearly described or implemented consistently. In 29 of the 50 studies that only measured prevalence, samples were obtained at a single time point. Only four of the studies that reported effectiveness of decontamination interventions were controlled trials, with most using cross-sectional or pre-post designs. Reporting of the effectiveness of interventions using statistical testing was poor or inconsistent. Few studies were designed in such a way that patient outcomes could be measured, that is, the direct impact of contamination on HAI. Reporting of results was frequently poor, with only 26 studies reporting the overall number and percentage of computer-related devices with bacterial contamination. Of the 50 studies reporting only baseline contamination, only 10 studies provided a CI or mean/median CFU, ATP or relative light unit value of keyboards or computer peripherals sampled. Full risk of bias tables can be found in online supplementary file 10

\section{DISCUSSION}

To the best of our knowledge, this is the first systematic review to report on the level of contamination of computer peripheral devices used in healthcare settings, as well as the effectiveness of interventions used to decontaminate these items. This review fills an important gap and provides substantial evidence from 75 studies and a total of 2804 devices, that is, computer peripheral devices, particularly keyboards, are potential reservoirs of infective pathogens. The overall proportion of contamination ranged from $24 \%$ to $100 \%$. Collectively, studies found a $96.7 \%$ contamination rate of keyboards sampled. Keyboards and other computer peripherals were most commonly contaminated with skin commensal bacteria, but also with a variety of other potential pathogenic bacteria including MRSA, C. diff, VRE and E. coli. Multiple interventions have been tested in attempts to decontaminate computer devices and keyboards in clinical settings, and several appear effective at reducing the overall level of contamination. Fourteen of the 25 interventional studies reported statistically significant reductions in contamination following the intervention. Effective interventions include: wipes/ pads using isopropyl alcohol, quaternary ammonium, 
Table 2 Studies reporting interventions that led to a significant reduction in contamination of computer peripheral devices

\begin{tabular}{|c|c|c|c|c|}
\hline Study & $\begin{array}{l}\text { Outcome } \\
\text { measures }\end{array}$ & Method used to decontaminate & Baseline contamination & Postintervention contamination \\
\hline $\begin{array}{l}\text { Codish et } a l^{24} \\
2015\end{array}$ & $\begin{array}{l}\text { Total bacterial } \\
\text { load }\end{array}$ & $\begin{array}{l}\text { MEDIWIPES (alcohol based) } \\
\text { versus TriGene (quaternary } \\
\text { ammonium based). Each device } \\
\text { decontaminated } 3 \times / \text { day }\end{array}$ & $\begin{array}{l}\text { Internal medicine: 92/92 (100\%) } \\
\text { ICU: } 62 / 70(88.6 \%) \\
\text { Total: } 154 / 162(95.1 \%)\end{array}$ & $\begin{array}{l}\text { Internal medicine: } 76 / 92(82.6 \%) \\
\text { ICU: } 31 / 70(44.3 \%) \\
\text { Total: } 107 / 162(66 \%) \\
P<0.001 \text { for both internal medicine }\end{array}$ \\
\hline
\end{tabular}

\begin{tabular}{|c|c|c|c|}
\hline $\begin{array}{l}\text { Duszak et al }{ }^{31} \\
2014\end{array}$ & $\begin{array}{l}\text { Total bacterial } \\
\text { load }\end{array}$ & $\begin{array}{l}\text { 'Chlorascrub' pads (chlorhexidine } \\
\text { gluconate and isopropyl alcohol) }\end{array}$ & $\begin{array}{l}\text { Bacterial growth found on } 100 \% \text { of } \\
\text { computer mice } \\
\text { Mean colony counts: } 46.1 \pm 58.1\end{array}$ \\
\hline $\begin{array}{l}\text { Fukada et } a l^{37} \\
2008\end{array}$ & $\begin{array}{l}\text { Total bacterial } \\
\text { load }\end{array}$ & $\begin{array}{l}\text { Cotton cellulose sheet dampened } \\
\text { with ethyl alcohol-intervention } \\
\text { only conducted in the OR }\end{array}$ & $\begin{array}{l}\text { Mean bacterial counts (SD): } \\
\text { OR: } 333(141) \\
\text { ICU: } 1015 \text { (501) } \\
\text { Consulting room and OPD reception } \\
\text { area: } 1113 \text { (1420) }\end{array}$ \\
\hline $\begin{array}{l}\text { Gostine et } a l^{39} \\
2016\end{array}$ & $\begin{array}{l}\text { Total bacterial } \\
\text { load }\end{array}$ & $\begin{array}{l}\text { UV Angel desktop lamps, set to } \\
\text { 3-min, 5-min, 6-min and 10-min } \\
\text { cycles }\end{array}$ & $\begin{array}{l}\text { 193/203 (95.1\%) samples, median of } \\
120 \text { CFUs per keyboard }\end{array}$ \\
\hline Jones et al ${ }^{47} 2015$ & $\begin{array}{l}\text { Total bacterial } \\
\text { load }\end{array}$ & $\begin{array}{l}\text { "CHG spray" (chlorhexidine } \\
\text { gluconate and isopropyl alcohol) } \\
\text { versus "TF spray" (chlorine } \\
\text { dioxide based) }\end{array}$ & $\begin{array}{l}57 \% \text { of keyboards had contamination } \\
\text { of }>500 \text { CFU } \\
\text { (Included: Bacillus spp., CNS, } \\
\text { micrococci and diphtheroids) }\end{array}$ \\
\hline
\end{tabular}

$\begin{array}{lll}\text { Martin et } a^{57} 2011 & \text { Total bacterial } & \begin{array}{l}\text { Keyboards with Vioguard UV light } \\ \text { load }\end{array} \\ & \begin{array}{l}\text { irradiation versus identical control } \\ \text { keyboards not exposed to UV } \\ \text { light irradiation }\end{array}\end{array}$

'Demonstrable bacterial colonisation was completely eradicated' for all four mice $(100 \%$ reduction)

In the OR: mean (SD) total bacteria counts reduced significantly (from $333[141]$ to $35[67] \mathrm{CFU} / \mathrm{mL})$ $P<0.05$

\section{$13 / 218(6 \%)$ samples}

contaminated, a $>99 \%$ reduction based on median CFU values (120 pre, 0 post). $P<0.0001$

$2 \%$ of keyboards had contamination of $>500 \mathrm{CFU}$ $(p \leq 0.001)$

(Only bacterial isolate was Bacillus spp.)

8/24 (33\%) had bacteria isolated.

\section{$P=0.001$}

(Primarily Gram-positive human flora and Gram-negative environmental flora. S. aureus and $P$. aeruginosa isolated from two control keyboards)

$\begin{array}{ll}\text { Messina et }\left.a\right|^{58} & \text { Total bacteria } \\ 2013 \text { (A) } & \text { count of: } \\ & \text { Staphylococci, } \\ & \text { E. coli, } \\ & \text { Pseudomonas, } \\ & \text { total coliform } \\ & \text { bacteria, } \\ & \text { Acinetobacter and } \\ \text { C. diff }\end{array}$

C. diff

$\begin{array}{lll}\begin{array}{l}\text { Messina et } a l^{59} \\ 2013(B)\end{array} & \begin{array}{l}\text { Total bacterial } \\ \text { load }\end{array} & \begin{array}{l}\text { Putty cleaning compound } \\ \text { (ethanol 29\%) with malleable- } \\ \text { elastic consistency }\end{array} \\ \text { Neely et a }{ }^{63} 1999 & \begin{array}{l}\text { Detection of } \\ \text { Acinetobacter } \\ \text { species }\end{array} & \begin{array}{l}\text { Enhanced cleaning policy: } \\ \text { required to wear gloves before } \\ \text { using computer and plastic } \\ \text { keyboard covers cleaned daily }\end{array}\end{array}$

Putty cleaning compound (ethanol 29\%) with malleableelastic consistency

(ac)
keyboards not exposed to UV

(

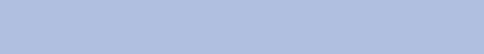

Total microbial load (at two different

Total microbial load (at two different
incubation temperatures):
$36^{\circ} \mathrm{C}: 26 / 27$ (96.3\%), CFU: 512
$22^{\circ} \mathrm{C}: 25 / 27$ (92.6\%), CFU 557

$36^{\circ} \mathrm{C}: 26 / 27$ (96.3\%), CFU: 512
$22^{\circ} \mathrm{C}: 25 / 27$ (92.6\%), CFU 557

Acinetobacter spp.: 1 (3.7\%)

E. coli: 11 (40.7\%)

Coliforms: 21 (77.8\%)

Enterococci: 4 (14.8\%)

Staphylococci: 25 (92.6\%)

MRSA: 6 (22.2\%)

Moulds: 20 (74.1\%)

$36^{\circ} \mathrm{C}: 2 / 27$ (7.4\%), CFU: 3

$22^{\circ} \mathrm{C}: 4 / 27$ (14.8\%), CFU: 18

Significant reductions in:

Coliforms: 2 (7.4\%), $p<0.0001$

Staphylococci: 1 (3.7\%), $p<0.0001$

Moulds: 1 (3.7\%), $p<0.0001$

E. coli: $0 \%, p=0.001$

Borderline or non-significant reductions in:

Enterococcus 0\%: $\mathrm{p}=0.045$ and MRSA 0\%: $p=0.014$

Total microbial load (at two different

incubation temperatures):

$36^{\circ} \mathrm{C}: 49 / 50$ (98\%)

$22^{\circ} \mathrm{C}: 33 / 50(66 \%)$

E. coli: $17 / 50(34 \%)$

Coliforms: $39 / 50(78 \%)$

Enterococci: 5/50 (10\%)

Staphylococci: 47/50 (94\%)

MRSA: 8/50 (16\%)

Moulds: $26 / 50$ (52\%)

13 acquired colonisations and 16

total colonisations of $A$. baumannii in

5 months preintervention

10 acquired colonisations and 34 total colonisations of $A$. baumannii in 19 months postintervention The number of acquired $A$. baumannii colonisations postintervention were significantly less than preintervention $(p<0.05)$ 


\begin{tabular}{|c|c|c|c|c|}
\hline Study & $\begin{array}{l}\text { Outcome } \\
\text { measures }\end{array}$ & Method used to decontaminate & Baseline contamination & Postintervention contamination \\
\hline $\begin{array}{l}\text { Shaikh et al }{ }^{77} \\
2016\end{array}$ & $\begin{array}{l}\text { Total bacterial } \\
\text { load }\end{array}$ & UV Angel system & $\begin{array}{l}20 / 25 \text { ( } 80 \%) \text { contaminated with any } \\
\text { potential pathogen, including Gram- } \\
\text { negative bacilli, C. diff, Enterococcus or } \\
\text { S. aureus }\end{array}$ & $\begin{array}{l}5 / 25(20 \%) \text { contaminated with any } \\
\text { potential pathogen }(p=0.0001) \\
\text { Total aerobic and facultative } \\
\text { bacteria: } 18 / 25(72 \%)(p=0.0006)\end{array}$ \\
\hline Xu et al/ 2017 & $\begin{array}{l}\text { Detection of } \\
\text { MRSA }\end{array}$ & $\begin{array}{l}\text { Cotton cloth and bucket system } \\
\text { versus disinfectant wipes }\end{array}$ & $\begin{array}{l}7 / 19(36.8 \%) \text { keyboards and mice } \\
\text { positive for MRSA }\end{array}$ & $\begin{array}{l}2 / 206 \text { (1\%) positive for MRSA. } \\
P<0.001\end{array}$ \\
\hline
\end{tabular}

A. baumannii, Acinetobacter baumannii; C. albicans, Candida albicans; C. diff, Clostridium difficile; CFU, colony forming unit; CNS, coagulase-negative staphylococcus; E. coli, Escherichia coli; ICU, intensive care unit; MRSA, methicillin-resistant Staphylococcus aureus; OPD, outpatient department; OR, operating room; P. aeruginosa, Pseudomonas aeruginosa; S. aureus, Staphylococcus aureus; S. epidermidis, Staphylococcus epidermidis; S. sanguinis, Streptococcus sanguinis; UV, ultraviolet.

chlorhexidine or dipotassium peroxodisulfate, UV light emitting devices, putty cleaning compounds, enhanced cleaning protocols and a keyboard with a cleaning alarm. However, results were inconsistent and there was insufficient data to provide robust recommendations on which method(s) are most effective to adopt routinely. Finally, there was insufficient data to demonstrate clear evidence of an association between contamination and human infection.

Current data are mostly limited to hospital settings. Almost all (63) of the included studies were conducted solely in hospitals, with a particular focus on ICUs. Only a small number of studies were conducted solely in ambulatory or outpatient settings.

\section{Comparison with the existing literature}

Our findings are consistent with a variety of literature on the potential contribution of contaminated hospital surfaces to human infection. ${ }^{91}$ Not only can environmental surfaces harbour dangerous pathogens, but evidence shows that pathogens, such as MRSA, can be transferred to healthcare workers' gloves or hands from contaminated surfaces. ${ }^{92-94}$ While some pathogens only survive a few days on inanimate surfaces, others, such as VRE, MRSA, Acinetobacter spp. and C. diff can survive for months if not properly cleaned or disinfected. ${ }^{95} 96$ Furthermore, some pathogens, such as VRE or C. diff, are more resistant to common disinfection methods than others. The link between environmental contamination and human infection has been difficult to establish firmly; however, various modelling studies, observational epidemiological studies, interventional studies, as well as outbreak reports suggest that this link exists. ${ }^{797} 98$
The optimal strategies for environmental disinfection in healthcare settings is unclear. Substantial evidence suggests that relying only on hand hygiene compliance among health workers is not an effective strategy. Two systematic reviews showed median rates of compliance with hand hygiene guidelines in hospital settings of $40 \%-57 \% .{ }^{99} 100$ Keyboards and computer devices pose additional challenges, including the difficulty of decontaminating their irregular surfaces and the potential for damage from cleaning products. ${ }^{101}$ While multiple methods to decontaminate environmental surfaces generally have been developed, but their effectiveness is unclear. ${ }^{96} 98102103$ Indeed, the CDC's Guidelines for Environmental Infection Control in Health-Care Facilities (updated in 2011) concluded that 'more research is required to clarify the effectiveness and reliability of fogging, UV irradiation, and ozone mists to reduce norovirus environmental contamination,' giving it a 'No recommendation/unresolved issue' rating. ${ }^{104}$ Results from our review suggest that little progress has been made in providing robust evidence for decontamination methods.

\section{Limitations of the review}

As with any systematic review, our findings are limited by the quantity and quality of the included studies. Heterogeneity across a number of areas limited our ability to conduct a meta-analysis and/or draw inferences from our findings. This included heterogeneity in the swabbing and microbiological identification methods, study settings, study timeframes, sample sizes and types of included devices. Outcome measures also varied; for example, some studies did not report a baseline contamination 
rate, and others did not specify the prevalence of specific pathogens identified. Fewer than half of the studies reported selection criteria that were prespecified, clearly described and implemented consistently. Only one study specifically sought to identify viruses (norovirus). ${ }^{61}$ Many potential pathogens were not specifically assessed in the included studies, and the data may represent an underestimate of contamination rates. Finally, nearly all included articles were conducted in hospital environments, and we have limited data on ambulatory or primary care settings.

\section{Implications for researchers, clinicians and policymakers}

Our findings indicate that the majority of keyboards and computer peripherals used in healthcare settings are contaminated with a range of microbes, including potential pathogens. However, determining the impact of this contamination on patients or healthcare workers was limited. Although we searched for studies reporting associations between contamination of computer-related equipment and infection or colonisation of patients/ healthcare workers, very few studies (5) were identified and the results of these were unclear and open to bias. Thus, our findings do not allow us to draw firm conclusions about the relative impact of these 'reservoirs' of contamination as sources of transmission between patients and healthcare staff, nor their impact on HAI or nosocomial infections. However, given that computers are ubiquitous in modern healthcare, it is possible that keyboards and peripherals may act as important, yet largely unrecognised sources of contamination and/or infection. Although evidence directly linking contaminated computer equipment and HAIs is scarce, evidence does demonstrate the effectiveness (although sometimes limited) of decontaminating potential fomites other than computer equipment as well as health workers' hands on reducing HAIs. ${ }^{797} 98$ 105-107 Given this evidence, there is an urgent need to identify whether the same benefits apply to decontaminating computer equipment.

Our review highlights priorities for further research in this area. First, there seems to be little need to further demonstrate the prevalence of contamination on computer-related devices. In contrast, however, the relative impact of computer device contamination on colonisation and infection of patients/healthcare workers is unclear currently; thus, future research should focus on clinically significant organisms and their potential for transmission to patients or health workers. Additionally, more robust study designs are needed for evaluating decontamination interventions, particularly ones that could be used in routine practice.

In conclusion, computer keyboards and other peripheral computer devices in hospital settings are frequently contaminated, often with potentially pathogenic microbes. It is unclear from current research how often these lead to HAI, and what measures clinicians and their staff should take (and how often) to ensure that their computers are sufficiently clean and do not pose risks for themselves or their patients.
Acknowledgements Many thanks to Sarah Safranik for assisting with the search strategy for the literature review.

Contributors $\mathrm{Nl}$ and MT designed the study methodology and conducted the literature search. NI extracted data from selected studies and MT checked extracted data for accuracy. NI and MT performed data analysis and developed the original draft of the article, and contributed towards further drafts. Data interpretation and critical revision of the manuscript was done by BKF, CML and PV. All authors reviewed and approved the manuscript.

Funding The authors have not declared a specific grant for this research from any funding agency in the public, commercial or not-for-profit sectors.

Competing interests None declared.

Patient consent for publication Not required.

Provenance and peer review Not commissioned; externally peer reviewed.

Data sharing statement The complete data extraction form, quality assessment tables, and full search strategy can be made available upon request to the study authors.

Open access This is an open access article distributed in accordance with the Creative Commons Attribution Non Commercial (CC BY-NC 4.0) license, which permits others to distribute, remix, adapt, build upon this work non-commercially, and license their derivative works on different terms, provided the original work is properly cited, appropriate credit is given, any changes made indicated, and the use is non-commercial. See: http://creativecommons.org/licenses/by-nc/4.0/.

\section{REFERENCES}

1. Magill SS, Edwards JR, Bamberg W, et al. Multistate pointprevalence survey of health care-associated infections. N Engl J Med 2014;370:1198-208.

2. Umscheid CA, Mitchell MD, Doshi JA, et al. Estimating the proportion of healthcare-associated infections that are reasonably preventable and the related mortality and costs. Infect Control Hosp Epidemiol 2011;32:101-14.

3. Rahmqvist M, Samuelsson A, Bastami S, et al. Direct health care costs and length of hospital stay related to health careacquired infections in adult patients based on point prevalence measurements. Am J Infect Control 2016;44:500-6.

4. Scott R. The direct medical costs of healthcare-associated infections in US hospitals and the benefits of prevention. Atlanta, GA: Centers for Disease Control and Prevention, 2009.

5. Weinstein RA. Epidemiology and control of nosocomial infections in adult intensive care units. Am J Med 1991;91:S179-S184.

6. de Oliveira AC, Damasceno QS. [Surfaces of the hospital environment as possible deposits of resistant bacteria: a review]. Rev Esc Enferm USP 2010;44:1118-23.

7. Otter JA, Yezli S, French GL. The role played by contaminated surfaces in the transmission of nosocomial pathogens. Infect Control Hosp Epidemiol 2011;32:687-99.

8. Weber DJ, Anderson D, Rutala WA. The role of the surface environment in healthcare-associated infections. Curr Opin Infect Dis 2013;26:338-44.

9. Dancer SJ. The role of environmental cleaning in the control of hospital-acquired infection. J Hosp Infect 2009;73:378-85.

10. Brady RR, Verran J, Damani NN, et al. Review of mobile communication devices as potential reservoirs of nosocomial pathogens. J Hosp Infect 2009;71:295-300.

11. Haun N, Hooper-Lane C, Safdar N. Healthcare Personnel Attire and Devices as Fomites: A Systematic Review. Infect Control Hosp Epidemiol 2016;37:1367-73.

12. Moher D, Liberati A, Tetzlaff J, et al. Preferred reporting items for systematic reviews and meta-analyses: the PRISMA statement. PLoS Med 2009;6:e1000097.

13. World Bank. World bank country and lending groups. 2017 https:// datahelpdesk.worldbank.org/knowledgebase/articles/906519world-bank-country-and-lending-groups (accessed 11 Jul 2017).

14. National Heart Lung Blood Institute. Assessing cardiovascular risk: systematic evidence review from the Risk Assessment Work Group. 2013 https://www.nhlbi.nih.gov/sites/default/files/media/docs/riskassessment.pdf (accessed 20 Jul 2018).

15. Livshiz-Riven I, Borer A, Nativ R, et al. Relationship between shared patient care items and healthcare-associated infections: a systematic review. Int J Nurs Stud 2015;52:380-92.

16. Albrecht UV, von Jan U, Sedlacek L, et al. Standardized, Appbased disinfection of iPads in a clinical and nonclinical setting: comparative analysis. J Med Internet Res 2013;15:e176. 
17. Al-Hamad A, Maxwell S. How clean is clean? Proposed methods for hospital cleaning assessment. J Hosp Infect 2008;70:328-34.

18. Ali S, Muzslay M, Wilson P. A novel quantitative sampling technique for detection and monitoring of clostridium difficile contamination in the clinical environment. J Clin Microbiol 2015;53:2570-4.

19. Anastasiades P, Pratt TL, Rousseau LH, et al. Staphylococcus aureus on computer mice and keyboards in intensive care units of the Universitas Academic Hospital, Bloemfontein, and ICU staff's knowledge of its hazards and cleaning practices. Southern African Journal of Epidemiology and Infection 2009;24:22-6.

20. Bures S, Fishbain JT, Uyehara CF, et al. Computer keyboards and faucet handles as reservoirs of nosocomial pathogens in the intensive care unit. Am J Infect Control 2000;28:465-71.

21. Cataño JC, Echeverri LM, Szela C. Bacterial contamination of clothes and environmental items in a third-level hospital in Colombia. Interdiscip Perspect Infect Dis 2012;2012:1-5.

22. Choi ES, Choi JH, Lee JM, et al. Is the environment of the endoscopy unit a reservoir of pathogens? Intest Res 2014;12:306-12.

23. Ciragil P, Gul M, Aral M. Bacterial contamination of computers and telephones in a university hospital in Turkey. J Hosp Infect 2006;62:247-8

24. Codish S, Toledano R, Novack V, et al. Effectiveness of stringent decontamination of computer input devices in the era of electronic medical records and bedside computing: a randomized controlled trial. Am J Infect Control 2015;43:644-6.

25. Cordeiro A, Oliveira MMC, Fernandes JD, et al. Equipment contamination in an intensive care unit. ACTA Paulista de Enfermagem 2015;28:160-5.

26. Dancer SJ, White L, Robertson C. Monitoring environmental cleanliness on two surgical wards. Int $J$ Environ Health Res 2008:18:357-64.

27. Dancer SJ, White LF, Lamb J, et al. Measuring the effect of enhanced cleaning in a UK hospital: a prospective cross-over study. BMC Med 2009;7:28.

28. De Grood J, Ward L, Harman S, et al. A cross-sectional point prevalence multi-hospital survey of health care associated pathogen contamination of computer keyboards. Can J Infect Dis Med Microbiol 2012;23:13B.

29. Devine J, Cooke RP, Wright EP. Is methicillin-resistant Staphylococcus aureus (MRSA) contamination of ward-based computer terminals a surrogate marker for nosocomial MRSA transmission and handwashing compliance? J Hosp Infect 2001;48:72-5.

30. Dumford DM, Nerandzic MM, Eckstein BC, et al. What is on that keyboard? Detecting hidden environmental reservoirs of Clostridium difficile during an outbreak associated with North American pulsed-field gel electrophoresis type 1 strains. Am J Infect Control 2009;37:15-19.

31. Duszak R, Lanier B, Tubbs JA, et al. Bacterial contamination of radiologist workstations: results of a pilot study. J Am Coll Radiol 2014;11:176-9.

32. Engelhart S, Fischnaller E, Simon A, et al. Microbial contamination of computer user interfaces (keyboard, mouse) in a tertiary care centre under conditions of practice. Hygiene + Medizin 2008:33:504-7.

33. Faires MC, Pearl DL, Ciccotelli WA, et al. A prospective study to examine the epidemiology of methicillin-resistant Staphylococcus aureus and Clostridium difficile contamination in the general environment of three community hospitals in southern Ontario, Canada. BMC Infect Dis 2012:12:290.

34. Faires MC, Pearl DL, Berke O, et al. The identification and epidemiology of meticillin-resistant Staphylococcus aureus and Clostridium difficile in patient rooms and the ward environment. BMC Infect Dis 2013;13:342

35. Fellowes C, Kerstein R, Clark J, et al. MRSA on tourniquets and keyboards. J Hosp Infect 2006;64:86-8.

36. Geadas Farias P, Gama F, Reis D, et al. Hospital microbial surface colonization revealed during monitoring of Klebsiella spp. Pseudomonas aeruginosa, and non-tuberculous mycobacteria. Antonie Van Leeuwenhoek 2017;110:863-76.

37. Fukada T, Iwakiri H, Ozaki M. Anaesthetists' role in computer keyboard contamination in an operating room. $J$ Hosp Infect 2008:70:148-53.

38. Gerba CP, Wuollet AL, Raisanen P, et al. Bacterial contamination of computer touch screens. Am J Infect Control 2016;44:358-60.

39. Gostine A, Gostine D, Donohue C, et al. Evaluating the effectiveness of ultraviolet-C lamps for reducing keyboard contamination in the intensive care unit: A longitudinal analysis. Am J Infect Control 2016:44:1089-94
40. Grabsch EA, Mahony AA, Cameron DR, et al. Significant reduction in vancomycin-resistant enterococcus colonization and bacteraemia after introduction of a bleach-based cleaning-disinfection programme. J Hosp Infect 2012;82:234-42.

41. Gray J, Mc Nicholl B, Webb H, et al. Mice in the emergency department: vector for infection or technological aid? Eur J Emerg Med 2007;14:160-2.

42. Hardy K, Abbott G, Bashford S, et al. Can measuring environmenta cleanliness using ATP aid in the monitoring of wards with periods of increased incidence of Clostridium difficile? J Infect Prev 2014;15:31-5

43. Hartmann B, Benson M, Junger A, et al. Computer keyboard and mouse as a reservoir of pathogens in an intensive care unit. $J$ Clin Monit Comput 2004;18:7-12.

44. Hassan RA. Rahman Bacterial contamination of computer keyboards and mouse. Tikri, Jourual of Pure Science 2014;19.

45. Hirsch EB, Raux BR, Lancaster JW, et al. Surface microbiology of the iPad tablet computer and the potential to serve as a fomite in both inpatient practice settings as well as outside of the hospital environment. PLOS One 2014:9:e111250.

46. Hong DY, Park SO, Lee KR, et al. Bacterial Contamination of Computer and Hand Hygiene Compliance in the Emergency Department. Hong Kong J Emerg Med 2012;19:387-93.

47. Jones R, Hutton A, Mariyaselvam M, et al. Keyboard cleanliness: a controlled study of the residual effect of chlorhexidine gluconate. Am J Infect Control 2015;43:289-91.

48. Jungnickel T, Von Jan U, Graf K, et al. Bugs! iPad-hygiene in healthcare. Biomedizinische Technik 2014:59:S1257-S60.

49. Karbasizade V, Sichani M, Parsafar S. Bacterial contamination of computer keyboards in hospitals in Isfahan in Iran. International Journal of Biosciences 2014:4:320-4.

50. Keerasuntonpong A, Kesornsuk S, Trakulsomboon S, et al. Colonization of Nosocomial Pathogens on Computer Keyboards in Patient Care Areas. Siriraj Medical Journal 2017;57:380-1.

51. Khan A, Rao A, Reyes-Sacin C, et al. Use of portable electronic devices in a hospital setting and their potential for bacterial colonization. Am J Infect Control 2015;43:286-8.

52. Kiedrowski LM, Perisetti A, Loock MH, et al. Disinfection of iPad to reduce contamination with Clostridium difficile and methicillin-resistant Staphylococcus aureus. Am J Infect Control 2013:41:1136-7.

53. Link T, Kleiner C, Mancuso MP, et al. Determining high touch areas in the operating room with levels of contamination. Am J Infect Control 2016;44:1350-5.

54. Lu PL, Siu LK, Chen TC, et al. Methicillin-resistant Staphylococcus aureus and Acinetobacter baumannii on computer interface surfaces of hospital wards and association with clinical isolates. BMC Infect Dis 2009;9:164.

55. Malta CP, Damasceno NN, Ribeiro RA, et al. Microbiological contamination in digital radiography: evaluation at the radiology clinic of an educational institution. Acta Odontol Latinoam 2016:29:239-47.

56. Man GS, Olapoju M, Chadwick MV, et al. Bacterial contamination o ward-based computer terminals. J Hosp Infect 2002;52:314-5.

57. Martin ET, Qin X, Baden H, et al. Randomized double-blind crossover trial of ultraviolet light-sanitized keyboards in a pediatric hospital. Am J Infect Control 2011;39:433-5.

58. Messina G, Ceriale E, Burgassi S, et al. Impact of a disinfecting technique on microbial contamination of computer keyboards and telephone handsets. J Hosp Adm 2013;2.

59. Messina G, Ceriale E, Lenzi D, et al. Environmental contaminants in hospital settings and progress in disinfecting techniques. Biomed Res Int 2013;2013:1-8.

60. Moore G, Muzslay M, Wilson AP. The type, level, and distribution of microorganisms within the ward environment: a zonal analysis of an intensive care unit and a gastrointestinal surgical ward. Infect Control Hosp Epidemiol 2013;34:500-6.

61. Morter S, Bennet G, Fish J, et al. Norovirus in the hospital setting: virus introduction and spread within the hospital environment. $J$ Hosp Infect 2011;77:106-12.

62. Motta RH, Groppo FC, Bergamaschi CC, et al. Isolation and antimicrobial resistance of Staphylococcus aureus isolates in a dental clinic environment. Infect Control Hosp Epidemiol 2007;28:185-90.

63. Neely AN, Maley MP, Warden GD. Computer keyboards as reservoirs for Acinetobacter baumannii in a burn hospital. Clinical infectious diseases: an official publication of the Infectious Diseases Society of America. United States 1999:1358-60.

64. Oguzkaya-Artan M, Baykan Z, Artan C, et al. Prevalence and risk factors for methicillin resistant Staphylococcus aureus carriage among emergency department workers and bacterial contamination 
on touch surfaces in Erciyes University Hospital, Kayseri, Turkey. Afr Health Sci 2015;15:1289-94.

65. Oie S, Yanagi $\mathrm{C}$, Matsui $\mathrm{H}$, et al. Contamination of environmental surfaces by Staphylococcus aureus in a dermatological ward and its preventive measures. Biol Pharm Bull 2005;28:120-3.

66. Otter JA, Passaretti CL, French GL, et al. Low frequency of environmental contamination with methicillin-resistan Staphylococcus aureus in an inner city emergency department and a human immunodeficiency virus outpatient clinic. Am J Infect Control 2011;39:151-3.

67. Patel S, Porter K, Sammons RL. Are computer keyboards a crossinfection risk in a dental clinic? Journal of Infection Prevention 2010;11:206-11.

68. Phumisantiphong $U$, Diraphat $P$, Utrarachkij F, et al. Clonal spread of carbapenem resistant Acinetobacter baumannii in the patients and their environment at BMA Medical College and Vajira Hospital. $J$ Med Assoc Thai 2009;92(Suppl 7):S173-80.

69. Pugliese A, Garcia AJ, Dobson W, et al. The prevalence of bacterial contamination of standard keyboards in an urban ED. Am J Emerg Med 2011;29:954-5.

70. Rastogi S, Shah R, Perlman J, et al. Pattern of bacterial colonization in a new neonatal intensive care unit and its association with infections in infants. Am J Infect Control 2012:40:512-5.

71. Reem RE, Van Balen J, Hoet AE, et al. Screening and characterization of Staphylococcus aureus from ophthalmology clinic surfaces: a proposed surveillance tool. Am J Ophthalmol 2014:157:781-7.

72. Richard RD, Bowen TR. What orthopaedic operating room surfaces are contaminated with bioburden? a study using the ATP bioluminescence assay. Clin Orthop Relat Res 2017;475:1819-24.

73. Rutala WA, White MS, Gergen MF, et al. Bacterial contamination of keyboards: efficacy and functional impact of disinfectants. Infect Control Hosp Epidemiol 2006;27:372-7.

74. Saito Y, Yasuhara H, Murakoshi S, et al. Time-dependent influence on assessment of contaminated environmental surfaces in operating rooms. Am J Infect Control 2015;43:951-5.

75. Schultz M, Gill J, Zubairi S, et al. Bacterial contamination of computer keyboards in a teaching hospital. Infect Control Hosp Epidemiol 2003;24:302-3.

76. Senok A, Garaween G, Raji A, et al. Genetic relatedness of clinical and environmental Acinetobacter baumanii isolates from an intensive care unit outbreak. J Infect Dev Ctries 2015;9:665-9.

77. Shaikh AA, Ely D, Cadnum JL, et al. Evaluation of a low-intensity ultraviolet-C radiation device for decontamination of computer keyboards. Am J Infect Control 2016;44:705-7.

78. Smith SJ, Knouse MC, Wasser T. Prevalence of bacterial pathogens on physician handheld computers. J Clin Outcomes Manag 2006;13:223-6.

79. Stambaugh RV, Elson L. Contaminated surfaces. Dimensions of Dental Hygiene 2009;7:5.

80. Sweeney CP, Dancer SJ. Can hospital computers be disinfected using a hand-held UV light source? J Hosp Infect 2009;72:92-4

81. Sykes A, Appleby M, Perry J, et al. An investigation of the microbiological contamination of ultrasound equipment. British Journal of Infection Control 2006;7:16-20.

82. Tan TY, Tan JS, Tay H, et al. Multidrug-resistant organisms in a routine ward environment: differential propensity for environmental dissemination and implications for infection control. J Med Microbiol 2013;62(Pt 5):766-72.

83. Trochesset DA, Walker SG. Isolation of Staphylococcus aureus from environmental surfaces in an academic dental clinic. J Am Dent Assoc 2012;143:164-9.

84. Waghorn DJ, Wan WY, Greaves C, et al. Contamination of computer keyboards in clinical areas: potential reservoir for nosocomial spread of organisms. British Journal of Infection Control 2005:6:22-4.

85. Westerway SC, Basseal JM, Brockway A, et al. Potential infection control risks associated with ultrasound equipment - a bacterial perspective. Ultrasound Med Biol 2017:43:421-6.

86. Wilson AP, Hayman S, Folan P, et al. Computer keyboards and the spread of MRSA. J Hosp Infect 2006;62:390-2.

87. Wilson AP, Ostro P, Magnussen M, et al. Laboratory and in-use assessment of methicillin-resistant Staphylococcus aureus contamination of ergonomic computer keyboards for ward use. Am $J$ Infect Control 2008;36:e19-e25.

88. Wilson AP, Smyth D, Moore G, et al. The impact of enhanced cleaning within the intensive care unit on contamination of the near-patient environment with hospital pathogens: a randomized crossover study in critical care units in two hospitals. Crit Care Med 2011;39:651-8

89. $\mathrm{Xu} \mathrm{H}, \mathrm{Chen} \mathrm{B}, \mathrm{Ni} \mathrm{X}$, et al. Computer keyboard and mouse: an intervention study on methicillin-resistant staphylococcus aureus decontamination in 4 intensive care units. J Crit Care 2017;37:266-7.

90. Yun HC, Kreft RE, Castillo MA, et al. Comparison of PCR/ electron spray ionization-time-of-flight-mass spectrometry versus traditional clinical microbiology for active surveillance of organisms contaminating high-use surfaces in a burn intensive care unit, an orthopedic ward and healthcare workers. BMC Infect Dis 2012;12:252.

91. Russotto V, Cortegiani A, Raineri SM, et al. Bacterial contamination of inanimate surfaces and equipment in the intensive care unit. $J$ Intensive Care 2015;3:54

92. Rusin P, Maxwell S, Gerba C. Comparative surface-to-hand and fingertip-to-mouth transfer efficiency of gram-positive bacteria, gram-negative bacteria, and phage. J Appl Microbiol 2002:93:585-92.

93. Stiefel U, Cadnum JL, Eckstein BC, et al. Contamination of hands with methicillin-resistant Staphylococcus aureus after contact with environmental surfaces and after contact with the skin of colonized patients. Infect Control Hosp Epidemiol 2011;32:185-7.

94. Boyce JM, Potter-Bynoe G, Chenevert C, et al. Environmental contamination due to methicillin-resistant Staphylococcus aureus: possible infection control implications. Infect Control Hosp Epidemiol 1997;18:622-7.

95. Kramer A, Schwebke I, Kampf G. How long do nosocomial pathogens persist on inanimate surfaces? A systematic review. BMC Infect Dis 2006;6:130.

96. Dancer SJ. Controlling hospital-acquired infection: focus on the role of the environment and new technologies for decontamination. Clin Microbiol Rev 2014;27:665-90.

97. Otter JA, Yezli S, Salkeld JA, et al. Evidence that contaminated surfaces contribute to the transmission of hospital pathogens and an overview of strategies to address contaminated surfaces in hospital settings. Am J Infect Control 2013;41(5 Suppl):S6-11.

98. Donskey CJ. Does improving surface cleaning and disinfection reduce health care-associated infections? Am J Infect Control 2013:41(5 Suppl):S12-19.

99. Erasmus V, Daha TJ, Brug H, et al. Systematic review of studies on compliance with hand hygiene guidelines in hospital care. Infect Control Hosp Epidemiol 2010;31:283-94.

100. Kingston L, O'Connell NH, Dunne CP. Hand hygiene-related clinical trials reported since 2010: a systematic review. J Hosp Infect 2016;92:309-20.

101. Dettenkofer M, Block C. Hospital disinfection: efficacy and safety issues. Curr Opin Infect Dis 2005:18:320-5.

102. Rutala WA, Weber DJ. Are room decontamination units needed to prevent transmission of environmental pathogens? Infect Control Hosp Epidemiol 2011;32:743-7.

103. Boyce JM. Modern technologies for improving cleaning and disinfection of environmental surfaces in hospitals. Antimicrobial Resistance \& Infection Control 2016:5:10.

104. Sehulster L, Chinn RY, CDCHICPAC. Guidelines for environmental infection control in health-care facilities. Recommendations of CDC and the Healthcare Infection Control Practices Advisory Committee (HICPAC). MMWR Recomm Rep 2003;52:1-42.

105. Ejemot-Nwadiaro RI, Ehiri JE, Arikpo D, et al. Hand washing promotion for preventing diarrhoea. Cochrane Database Syst Rev 2015;9:Cd004265

106. Falagas ME, Thomaidis PC, Kotsantis IK, et al. Airborne hydrogen peroxide for disinfection of the hospital environment and infection control: a systematic review. J Hosp Infect 2011;78:171-7.

107. Murphy CR, Eells SJ, Quan V, et al. Methicillin-resistant Staphylococcus aureus burden in nursing homes associated with environmental contamination of common areas. J Am Geriatr Soc 2012;60:1012-8. 